\title{
INTEGRASI ILMU DI SEKOLAH DASAR \\ (Studi Kasus Kurikulum Terpadu di SDIT Lukman Al-Hakim Surakarta)
}

\author{
Suyatno \\ Program Studi Pendidikan Sekolah Dasar, Fakultas Keguruan dan Ilmu Pendidikan, \\ Universitas Ahmad Dahlan Yogyakarta \\ e-mail: broery_jis@yahoo.co.id
}

\begin{abstract}
The growing dichotomy in the world of science education today has been split into two faces of education in the extreme polar opposites. On the one hand, there is a general educational institutions under the auspices of the Ministry of Education and Culture. By most Muslims, this institution was branded as a secular institution, because the science is developed far from the values of monotheism. On the other hand, there are religious institutions (adrasas) which is under the Ministry of Religious Affairs. For secular scientists, educational institutions is considered obsolete because science is pseudo science developed. Such polarization would be detrimental to human life due sciences developed in two models of educational institutions are not able to resolve the problems faced by modern man. Secular science without the spirit of monotheism will make man alienated from himself, while the science of religion as such, causes people not able to face the challenges and changing times. Therefore, it takes an alternative educational institution that develops in integrated science, which combines general sciences and theology. The birth of the Islamic Primary School Integrated Lukman al - Hakim is a response to the dichotomy.
\end{abstract}

\begin{abstract}
Abstrak: Dikotomi ilmu yang berkembang dalam dunia pendidikan saat ini telah membelah wajah pendidikan menjadi dua kutub yang berlawanan secara ekstrim. Di satu sisi, ada lembaga pendidikan umum yang berada di bawah naungan Kementerian Pendidikan dan Kebudayaan. Oleh sebagian umat Islam, lembaga pendidikan ini dicap sebagai lembaga pendidikan sekuler, karena ilmu yang dikembangkan jauh dari nilai-nilai tauhid. Di sisi lain, ada lembaga pendidikan agama (madrasah) yang berada di bawah Kementerian Agama. Bagi ilmuwan sekuler, lembaga pendidikan ini dianggap ketinggalan zaman karena ilmu-ilmu yang dikembangkan bersifat pseudo ilmiah. Polarisasi yang demikian tentu akan merugikan kehidupan manusia karena ilmu-ilmu yang dikembangkan di dua model lembaga pendidikan tersebut tidak mampu menyelesaikan permasalahan yang dihadapi manusia modern. Ilmu sekuler tanpa spirit tauhid akan menjadikan manusia teralienasi dari dirinya sendiri, sedangkan ilmu agama an sich menyebabkan manusia tidak mampu menghadapi tantangan dan perubahan zaman. Oleh karena itu, dibutuhkan sebuah lembaga pendidikan alternatif yang mengembangkan keilmuan secara integratif, yang memadukan antara ilmu-ilmu umum dan ilmu agama. Lahirnya Sekolah Dasar Islam Terpadu Lukman al-Hakim merupakan respon terhadap adanya dikotomi tersebut.
\end{abstract}

\section{Kata Kunci: Integrasi IImu, Kurikulum Terpadu, SDIT Lukman al-Hakim}

\section{Pendahuluan}

Pada dekade akhir Orde Baru dan di lanjutkan Orde Reformasi, ada perkembangan menarik mengenai perkembangan pen didikan di Indonesia. Hal ini ditandai dengan muncul dan berkembangnya Sekolah- sekolah Islam Terpadu. Lembaga pendidikan yang diprakarsai pertama kali oleh para aktivis masjid kampus Universitas Indonesia dan Institut Teknologi Bandung (Ali Said Damanik, 2003: 157) telah mampu menarik minat para orang tua dari kalangan menengah Muslim Indonesia. Tidak tang- 
gung-tanggung, kurang lebih dalam kurun waktu 20 tahun, lembaga ini telah tersebar di seluruh pelosok Indonesia. Jumlah sekolah ini telah mencapai 10.000 sekolah dan 1.000 diantaranya telah terdaftar sebagai anggota Jaringan Sekolah Islam Terpadu (JSIT) Indonesia (Usamah Hisyam, 2011: 67) dimana JSIT sendiri dibagi menjadi 7 daerah kepengurusan di seluruh Indonesia (Profil JSIT Wilayah Yogyakarta, 2012).

Persebaran lembaga pendidikan yang demikian pesat ini tentu didukung oleh banyak faktor, baik faktor internal maupun eksternal. Sebagaimana disampaikan oleh Coleman, orang tua memilih lembaga pendidikan bagi putra-putrinya adalah berdasarkan preferensi tertentu (George R. Ritzer dan Douglas J Goodman, 2007). Dalam faktor eksternal, setidaknya ada dua fenomena yang dapat menjelaskan mengapa sekolah ini berkembang di Indonesia. Pertama, munculnya kelas menengah Muslim Indonesia. Kemunculan kelas ini sebenarnya sudah dimulai sejak tahun 1980an (Kuntowijoyo, 1985) ketika kalangan Muslim santri mulai menempati jabatan-jabatan profesional baik di lingkungan lembaga pemerinhan maupun swasta. Puncaknya adalah terbentuknya Ikatan Cendekiawan Muslim seIndonesia (ICMI) yang diketuai oleh B.J. Habibie (Syafii Anwar 1995: 120).

Duduk sebagai Dewan Redaksi adalah para Muslim modernis seperti Adi Sasono, Quraish Shihab, Sutjipto Wirosardjono, Marwah Daud Ibrahim, Haidar Bagir, Azyumardi Azra, Kuntowijoyo dan Imaduddin Abdulrahim. Orang-orang ini adalah para aktifis ICMI. Selain meningkatnya kemampuan ekonomi mereka, kelas menengah Muslim juga ditandai dengan meningkatnya semangat untuk mengamalkan nilai-nilai keislaman (Hefner, 1996: 152-153). Mereka tidak lagi merasa malu untuk menampakkan simbol-simbol keagaman di ruang publik, semisal memakai jilbab, datang ke majelis pengajian, dan memakai asesoris Teori Habitus dan Kelas Menengah Muslim
Indonesia). Dampak lebih lanjut dari fenomena ini adalah mereka menginginkan generasi mereka memiliki basis pengetahun agama yang kuat sehingga dapat menjadi benteng dalam pergaulan dunia yang semakin maju. Memasukkan putra-putri mereka ke sekolah-sekolah Islam merupakan salah satu pilihan yang rasional.

Kedua, politik akomodasi Orde Baru. Sebagaimana dipahami, rezim Orde Baru yang dikomandoi oleh Presiden Soeharto telah mengubah haluan politiknya pada akhir dekade tahun 1980an. Pemerintah Orde Baru mulai merangkul tokoh-tokoh Muslim untuk mengisi jabatan-jabatan penting di pemerintahan. Adanya politik akomodasi Orde Baru mengakibatkan tokoh-tokoh Muslim, dan dalam lingkup yang lebih besar berupa gerakan Islam, mulai terbuka dan tidak lagi takut untuk melakukan gerakan secara terbuka dan dalam sekala yang lebih besar. Terkait khusus dengan tema penelitian ini, gerakan Jamaah Tarbiyah yang pada awalnya hanya melakukan gerakan pada lingkup informal, telah berani bergerak lebih terbuka ke ruang publik dengan mendirikan Sekolah Islam Terpadu, yang notabene merupakan lembaga pendidikan formal yang secara resmi berada di bawah Sistem Pendidikan Nasional (Suyatno, 2013).

Sedangkan faktor internal, muncul da$\mathrm{n}$ berkembangnya Sekolah Islam Terpadu disebabkan oleh adanya keprihatinan oleh para aktivis Muslim terhadap adanya dikotomi Sistem Pendidikan Nasional (Wawancara dengan Ketua JSIT Wilayah Yogyakarta). Dikotomi Sistem Pendidikan Nasional ditandai dengan adanya dualisme pengelolaan antara lembaga pendidikan di bawah Kementerian Pendidikan dan Kebudayaan dan lembaga pendidikan di bawah naungan Kementerian Agama. Sekolah-sekolah umum dari tingkat Taman Kanak-kanak, Sekolah Dasar, SMP, SMA, hingga perguruan tinggi umum merupakan lembaga pendidikan yang berada di bawah naungan Kementerian Pendidikan dan Kebudayaan. 
Sedangkan RA, MI, MTs, MA, hingga Perguruan Tinggi Agama Islam merupakan lembaga pendidikan yang berada di bawah naungan Kementerian Agama. Dua model lembaga pendidikan tersebut selain terpisah dalam pengelolaan, juga terpisah dalam epsitemologi keilmuannya. Model sekolah yang pertama dianggap sebagai lembaga pendidikan sekuler karena mengajarkan ilmuilmu umum yang terlepas dari ajaran agama, di sisi lain, model lembaga pendidikan yang kedua dianggap sebagai lembaga pendidikan yang mengajarkan ilmu-ilmu yang pseudo-ilmiah karena tidak dapat dibuktikan secara empiris (Mulyadi Kartanegara, 2005).

Adanya dikotomi tersebut setidaknya menyebabkan empat pokok masalah sebagai berikut; Pertama, munculnya ambivalensi dalam sistem pendidikan Islam. Kedua, munculnya kesenjangan antara sistem pendidikan Islam dan ajaran Islam. Ketiga, terjadinya disintegrasi sistem pendidikan Islam. Dan keempat, munculnya inferioritas pengelola lembaga pendidikan Islam

Kondisi demikian tentu menyebabkan pendidikan mengalami kerugian, karena yang dihasilkan oleh model-model sekolah tersebut adalah manusia yang tertinggal oleh kemajuan ilmu pengetahuan di satu sisi dan di sisi lain juga tertinggal dalam pengetahuan agama. Tertinggal dalam bidang ilmu pengetahuan dikarenakan tidak seluruh waktu dan potensinya digunakan untuk mempelajari ilmu pengetahuan akibat kurikulum yang harus dijalani. Tertinggal dalam bidang agama dikarenakan kurikulum yang ada hanya terdapat sedikit pelajaran agama, itupun materinya sudah terjauhkan dari nilai-nilai tauhid. Hal itu menyebabkan usaha untuk mengubah atau membentuk sosok pribadi Muslim sesuai yang diidamkan oleh pendidikan Islam sangat kecil. Oleh karena itu dibutuhkan lembaga pendidikan Islam alternatif yang mampu menghapus dikotomi ilmu pengetahuan (Suyatno, 2012).
Sekolah Dasar Islam Terpadu (SDIT) Lukman al-Hakim Surakarta adalah salah satu lembaga pendidikan alternatif yang berusaha menghapus adanya dikotomi ilmu pengetahuan. Lembaga ini merupakan produk pemikiran alternatif sebagai upaya pengembangan sistem pendidikan Islam dalam jangkauan masa depan. Dasar pemikiran dengan istilah terpadu merupakan jawaban dari pola pikir pendidikan yang dikotomis yang diterapkan di negeri yang agamis ini.

Kurikulum yang diterapkan oleh SDIT Lukman al-Hakim Surakarta berbeda dengan kurikulum yang diterapkan oleh madrasah, sekolah umum, maupun pesantren. Kurikulum yang diterapkan di madrasah dan sekolah umum adalah kurikulum yang memisahkan secara substansial antara mata pelajaran umum dan mata pelajaran agama. Hal itu terlihat dengan adanya prosentase komposisi kurikulum yang diterapkan oleh kedua model sekolah tersebut. Kurikulum yang diterapkan pesantren adalah kurkulum yang hanya sebatas mengajarkan ilmu-ilmu teks keagamaan semata, misalnya; Aqidah, Akhlaq, Qur'an, Hadist, Fiqih, dan Tarikh. Kurikulum yang diterapkan oleh SDIT Lukman al-Hakim Surakarta tidak mengenal adanya pembagian prosentase antara mata pelajaran umum dan mata pelajaran agama, karena tujuan dari semua mata pelajaran adalah mengantarkan peserta didik menjadi output pendidikan yang mumpuni dalam ilmu agama dan umum yang terpadu secara maksimal dalam ranah kognitif, afektif, dan psikomotorik (Dokumentasi Profil SDIT Lukman al-Hakim Surakarta).

Mata pelajaran dalam kurikulum SDIT Lukman al-Hakim Surakarta terdiri dari kurikulum pesantren, kurikulum kementreian agama, dan kurikulum dari Kementerian Pendidikan dan Kebudayaan yang telah diinovasi. Kurikulum dari pesantren diwujudkan dalam bentuk mata pelajaran Praktek Ibadah, Tahfidz, Tadarus, Bahasa Arab, dan Tajwid/Murotal. Kurikulum dari Kementri- 
an Agama diwujudkan dalam bentuk mata pelajaran al-Qur'an, Hadits, Tarikh, Fikih, dan Akidah-Akhlak. Meskipun demikian, adanya pembedaan mata pelajaran tersebut tidak menimbulkan adanya pemisahan secara substansial antara ilmu umum dan ilmu agama. Mata pelajaran tersebut terpadu secara integral dalam satu paket kurikulum berbasis tauhid. Hal tersebut membuktikan adanya usaha untuk mengintegrasikan antara ilmu agama dan ilmu umum sehingga berjalan secara terpadu (tidak ada dikotomi antara ilmu agama dan ilmu umum). Berdasarkan latar belakang masalah di atas, tulisan ini berusaha menjawab pertanyaan sebagai berikut; Pertama, bagaimanakah konsep dasar integrasi ilmu di SDIT Lukman al-Hakim Surakarta? Kedua, apakah implikasi integrasi ilmu dalam pengembangan kurikulum pendidikan di SDIT Lukman alHakim Surakarta?

\section{Konsep Integrasi Ilmu}

Secara etimologi, dikotomi berasal dari bahasa inggris "dichotomy" yang berarti pembagian dalam dua bagian, pembagian dua, bercabang dalam dua bagian (Jhon M. Echols, Hasan Sadily, 1992: 180). Dalam bahasa Indonesia, dikotomi berarti bagian dari dua kelompok yang saling bertentangan (Departemen Pendidikan dan Kebudayaan, 1989: 205). Secara terminologi, dikotomi adalah pemisahan antara ilmu dan agama yang kemudian berkembang menjadi fenomena-fenomena dikotomik yang lain, seperti dikotomi ulama-intelektual, dikotomi dalam dunia pendidikan Islam dan bahkan dikotomi dalam diri manusia muslim itu sendiri (split personality) (Ahmad Watik Pratiknya, 1991: 104). Sementara itu, menurut al-Faruqy, dikotomi adalah dualisme relegius dan cultural (Ismail Raji' alFaruqy 1992: 87).

Proses terciptanya dikotomi, menurut Amrullah Ahmad, adalah sebagai berikut: pertama, kegagalan dalam merumuskan tau- hid dan bertauhid; kedua, kegagalan butir pertama di atas menyebabkan lahirnya syirik yang berakibat lahirnya dikotomi fikrah islami; ketiga, dikotomi fikrah islami menyebabkan dikotomi kurikulum; keempat, dikotomi kurikulum menyebabkan terjadinya dikotomi dalam proses pencapaian tujuan pendidikan; kelima, dikotomi dalam proses pencapaian tujuan dalam interaksi sehari-hari dilembaga pendidikan menyebabkan dikotomi alumnus lembaga pendidikan dalam bentuk split-personality ganda dalam arti kemusyrikan, kemunafikan yang melembaga dalam keyakinan, sistem pemikiran, sikap, cita-cita dan perilaku yang sering disebut sekulerisme; keenam, suasana dikotomik ini melembaga dalam sistem pengelolaan pendidikan Islam yang ditandai dengan tradisi mengulurkan tangan untuk meminta bantuan secara politis dengan alasan subjektif atau objektif; bahwa terjadi krisis dalam penyelenggaraan pendidikan; ketujuh, lembaga pendidikan akan melahirkan manusia yang berkepribadian ganda yang justru melahirkan dan memperkokoh sistem kehidupan umat yang sekuleristik, rasionalistik, intuitif dan materialistik; kedelapan tata kehidupan umat yang demikian itu hanya mampu melahirkan kebudayaan Barat sekuler yang diperoleh dengan nama Islam; kesembilan, dalam proses regenerasi umat, maka tampillah da'i yang berusaha memisahkan kehidupan sosial, politik, ilmu pengetahuan-teknologi, dan ekonomi dengan ajaran Islam. Agama adalah urusan akhirat dan ilmu teknologi untuk urusan dunia (Amrullah Achmad, 1991: 52-53).

Sementara itu, Ziauddin Sardar memberikan solusi untuk menghilangkan dikotomi itu yakni dengan cara meletakkan epistemologi dan teori sistem pendidikan yang bersifat mendasar. Menurutnya, untuk menghilangkan sistem pendidikan dikotomis di dunia Islam perlu dilakukan usaha-usaha sebagai berikut:

Pertama, dari segi epistemologi umat Islam harus berani mengembangkan kera- 
ngka pengetahuan masa kini yang terartikulasi sepenuhnya. Ini berarti kerangka pengetahuan yang dirancang harus aplikatif, tidak sekedar menara gading saja.

Kedua, perlu suatu kerangka teoritis ilmu dan teknologi yang menggambarkan gaya-gaya dan metode-metode aktivitas ilmiah dan teknologi yang sesuai tinjauan dunia dan mencerminkan nilai dan moral Islam.

Ketiga, perlu diciptakan teori-teori sistem pendidikan yang memadukan ciriciri terbaik sistem tradisional dan sistem modern. Sistem pendidikan yang integralistik itu secara sentral harus mengacu pada konsep ajaran Islam, misalnya konsep tazkiyatun nafs, tauhid dan sebagainya (Ziauddin Sardar, 1998: 280-281).

Tampaknya metode penyelesaian dikotomi yang ditawarkan Sardar di atas bersifat mendasar, oleh karenya membutuhkan waktu yang cukup lama. Namun demikian bila diusahakan secara serius tentu akan didapatkan hasil yang nyata.

Sejalan dengan pendapat Sardar, alFaruqi mengatakan bahwa dikotomi sistem pendidikan Islam yang telah menjadikan "malaise" (penyakit) umat hanya dapat diobati dengan injeksi epistemologis. Tidak dapat diharapkan adanya kebangkitan kembali umat jika sistem pendidikannya tidak diubah dan kesalahan-kesalahannya tidak dikoreksi. Karenanya sistem pendidikan harus diperbaharui. Dualisme sistem pendidikan Islam yang ada sekarang, bifukasi (pencabang-duaan)-nya menjadi sistem Islam dan sistem sekuler, harus dihilangkan dengan cara mengintegrasikan kedua sistem itu, sementara sistem yang akan muncul harus diinfus dengan spirit Islam dan berfungsi sebagai bagian dari program ideologisnya (Ziauddin Sardar, 1998: 44-45).

\section{Model-model Integras iIlmu}

Hanna Djumhana Bastaman, seorang psikolog Muslim, mengemukakan bahwa a- da beberapa bentuk pola integrasi keilmuan mulai dari bentuk yang paling superficial sampai dengan bentuk yang paling mendasar, yang diistilahkan sebagai berikut:

1. Similarisasi, yaitu menyamakan begitu saja konsep-konsep sains dengan konsep-konsep yang berasal dari agama, padahal belum tentu sama. Misalnya, dalam psikologi, menganggap ruh sama dengan jiwa, atau al-nafs al-amarah, nafs al-lawwamah, dan nafs al muthmainnah dari al-Qur' an dianggap identik dengan konsep-konsep id, ego, dan superego.

2. Paralelisasi, yaitu menganggap paralel konsep yang berasal dari al-Qur'an dengan konsep yang berasal dari sains karena kemiripan konotasinya, tanpa mengidentikkan keduanya. Misalnya menganggap perang dunia III sejalan dengan kiamat, atau menjelaskan isra' mi' raj paralel dengan perjalanan ke ruang angkasa dengan menggunakan rumus fisika $\mathrm{s}=\mathrm{v}$ x t (jarak = kecepatan $\mathrm{x}$ waktu), di mana faktor kecepatannya $=$ tak terhingga. Paralelisasi sering digunakan sebagai penjelasan ilmiah kebenaran ayat-ayat al-Qur'an dalam rangka menyebarkan syi'ar Islam kepada kelompok masyarakat terpelajar.

3. Komplementasi, yaitu antara sains dan agama saling mengisi dan memperkuat satu sama lain, tetapi tetap mempertahankan eksistensi masing-masing. Misalnya manfaat puasa ramadhan (untuk kesehatan) dijelaskan dengan prinsipprinsip dietary dari ilmu kedokteran. Atau kebijakan keluarga berencana didukung oleh ayat-ayat al-Qur'an dan alHadis Nabi Saw. Dalam hal ini tampaknya terjadi saling mengabsahkan/justifikasi antara sains dan agama.

4. Komparasi, yaitu membandingkan konsep/teori sains dengan konsep/wawasan agama mengenai gejala-gejala yang sama. Misalnya teori motivasi dari psikologi dibandingkan dengan konsep moti- 
vasi yang dijabarkan dari ayat-ayat alQur'an.

5. Induktifikasi, yaitu asumsi-asumsi dasar dari teori-teori ilmiah yang didukung oleh temuan-temuan empirik dilanjutkan pemikirannya secara teoritis abstrak ke arah pemikiran metafisik/goib kemudian dihubungkan dengan prinsip-prinsip agama dan al-Qur'an mengenai hal tersebut. Teori adanya "sumber gerak yang tak bergerak" dari Aris Toteles misalnya merupakan contoh dari induktifikasi dari pemikiran sains ke pemikiran agama. Contoh lainnya adalah adanya keteraturan dan keseimbangan yang sangat menakjubkan di dalam alam semesta ini menyimpulkan hukum maha besar yang mengatur.

6. Verivikasi yaitu mengungapkan hasilhasil penelitian ilmiah yang menunjang dan membuktikan kebenaran-kebenaran (ayat-ayat) al-Qur'an. Misalnya penelitian mengenai potensi madu sebagai obat yang dihubungkan dengan surat an-nahl ayat yang ke 69 (Hanna Djumhana Bastaman, 1997: 32-33).

\section{Metodologi Penelitian}

Penelitian ini bersifat deskriptif kualitatif. Penelitian deskriptif yaitu jenis penelitian yang memberikan gambaran atau uraian atas sesuatu keadaan sejelas mungkin tanpa ada perlakuan terhadap objek yang diteliti (Roni Kountur, 2005: 105). Penelitian diarahkan untuk mendapatkan gambaran secara objektif tentang objek yang diteliti.

Penelitian ini menggunakan metode kualitatif yang menurut Bogdan dan Taylor didefinisikan sebagai prosedur penelitian yang menghasilkan data deskriptif berupa kata-kata tertulis atau lisan tentang orangorang dan perilaku yang dapat diamati (Lexy J. Moleong, 2005: 4).

Pemilihan subjek penelitian dilaksanakan dengan purposive sampling yaitu untuk menjaring sebanyak mungkin informasi yang dijadikan dasar dari rancangan dan teori yang muncul. Oleh karena itu dalam penelitian ini digunakan sampel bertujuan (purposive sample). Subjek penelitian diperoleh dari informan kunci, yakni informan yang diduga mengetahui secara persis tentang situasi kondisi latar penelitian karena informan adalah orang yang dimanfaatkan untuk memberikan informasi tentang situasi dan kondisi latar penelitian (Sugiyono, 2008: 124). Informan kunci dalam penelitian ini adalah wakil kepala sekolah bidang kurikulum.

Adapun secara keseluruhan narasumber penelitian dalam penelitian ini adalah:

a. Kepala SDIT Lukman al-Hakim Surakarta.

b. Wakil Kepala Sekolah Bidang Kurikulum SDIT Lukman al-Hakim Surakarta.

c. Para Guru SDIT Lukman al-Hakim Surakarta.

d. Para Siswa SDIT Lukman al-Hakim Surakarta.

3. Metode Pengumpulan Data

Penelitian lapangan ini menggunakan metode pengumpulan data yakni:

a. Metode Observasi

Metode ini digunakan untuk mendapatkan data visual secara luas tentang keadaan lingkungan SDIT Lukman al-Hakim Surakarta, situasi pembelajaran di kelas, sarana-prasarana yang dimiliki oleh sekolah, dan kondisi-kondisi lainnya yang mendukung data visual.

b. Metode Wawancara atau Interview

Penelitian ini menggunakan wawancara bebas terpimpin, yaitu komunikasi antara interview bebas dan interview terpimpin yang pelaksanaannya dengan membawa pedoman berupa garis besar tentang hal-hal yang akan ditanyakan (Cholid Narko dan Abu Achmadi, 2005: 83). Pedoman wawancara ini dilakukan untuk menghindari kemungkinan melupakan beberapa persoalan yang relevan serta sebagai bimbingan secara mendasar tentang apa yang diungkapkan. Interview guide ini berisi sejumlah perta- 
nyaan atau pernyataan tentang fakta, data, pengetahuan, konsep, persepsi, atau evaluasi informan, tentang hal-hal yang menyangkut integrasi ilmu dan implikasinya terhadap situasi pembelajaran di kelas, proses dan cara perekrutan guru, silabus pembelajaran dan lain-lain di SDIT Lukman alHakim Surakarta.

\section{c. Metode Dokumentasi}

Metode dokumentasi merupakan suatu teknik pengumpulan data dengan menghimpun dan menganalisis dokumen-doku men baik dokumen tertulis, gambar maupun elektronik (Nana Syaudih Sukma Dinata, 2004: 221). Pengumpulan data melalui metode ini dilakukan dengan menghimpun dokumen-dokumen SDIT Lukman al-Hakim antara lain buku profil sekolah, dokumen kurikulum, struktur organisasi sekolah, silabus pembelajaran, rencana pelaksanaan pembelajaran, dan arsip-arsip lain sehingga dapat diperoleh gambaran secara utuh terutama tentang kurikulum di SDIT Lukman al-Hakim.

\section{Pemeriksaan Keabsahan Data}

Sebelum melakukan langkah analisis data, diperlukan adanya teknik pemeriksaan terhadap keabsahan data yang diperoleh. Pemeriksaan keabsahan data didasarkan pada kriteria derajat kepercayaan (credibility) yaitu pemeriksaan keabsahan data yang berfungsi sebagai: Pertama, melaksanakan inkuiri sedemikian rupa sehingga tingkat kepercayaan penemuannya dapat dicapai. Kedua, mempertunjukkan derajat kepercayaan hasil-hasil penemuan dengan jalan pembuktian pada kenyataan ganda yang diteliti (Lexy J. Moleong, 2005: 324).

Berdasarkan kriteria ini, maka teknik yang digunakan adalah triangulasi, yaitu teknik pemeriksaan keabsahan data yang memanfaatkan sesuatu yang lain di luar data itu untuk keperluan pengecekan atau sebagai pembanding terhadap data itu. Triangulasi yang digunakan dalam penelitian ini yakni, pertama, triangulasi sumber yaitu dengan membandingkan dan mengecek balik derajat kepercayaan suatu informasi yang diperoleh melalui sumber yang berbeda (Lexy J. Moleong, 2005: 330). Kedua, triangulasi metode dengan menggunakan berbagai metode pengumpulan data untuk menggali data yang sejenis.

\section{Konsep Dasar Integrasi Ilmu di SDIT Lukman al-Hakim Surakarta}

Wacana integrasi sebenarnya sudah berkembang pada abad-abad terdahulu, sebagaimana telah banyak dikemukakan oleh ilmuwan-ilmuwan di dunia Muslim. Meskipun demikian, wacana tersebut sampai saat ini secara resmi masih jarang menjadi karaktersitik dari sebuah lembaga pendidikan. Pengertian integrasi itu sendiri hingga saat ini masih terjadi diskusi panjang. Praktek pendidikan di berbagai lembaga lembaga pendidikan yang berkembang di Indonesia masih menunjukkan adanya dikotomi antara pendidikan umum dan pendidikan agama.

Berbeda dengan dikotomi yang dikenal oleh dunia Islam, sains modern Barat sering menganggap rendah status keilmuan ilmu-ilmu agama. Ketika berbicara tentang ilmu-ilmu goib, ilmu agama tidak bisa dipandang ilmiah karena sebuah ilmu bisa dipandang ilmiah apabila objek-objeknya bersifat empiris. Padahal ilmu-ilmu agama tentunya tidak bisa menghindar dari membicarakan hal-hal yang goib.

Kondisi yang demikian itu menjadi keprihatinan sebagian para aktivis pendidikan, terutama dari kalangan Muslim. Mereka mencoba untuk mendirikan sebuah model lembaga pendidikan yang dapat menjadi alternatif solusi dari permasalahan itu. SDIT Lukman al-Hakim Surakarta menjadi salah satu lembaga pendidikan yang lahir dari kerpihatinan tersebut. Untuk melihat bagaimanakah konsep integrasi ilmu di SDIT Lukman al-Hakim dapat diungkap dari pandangan para guru maupun kepala sekolah baik yang mengampu mata pelajaran umum maupun mata pelajaran keagamaan. Namun 
demikian, sebenarnya pandangan umum para stakeholder sekolah dapat dilihat dari rumusan visi dan misi sekolah.

SDIT Lukman al-Hakim adalah sebuah lembaga pendidikan yang menganggap bahwa semua ilmu sebenarnya berasal dari satu sumber yakni Allah swt. Baik ilmuilmu agama (aqliyah) maupun ilmu-ilmu umum (naqliyah) merupakan ilmu yang berasal dari Tuhan yang satu sehingga keduanya tidak mungkin berseberangan. Hal ini dapat dilihat dari visi dan misi SDIT Lukman al-Hakim dalam bidang kependidikan yakni menyelenggarakan pendidikan secara integral dalam aspek ruhiyah, aqliyah, dan jismiyah sehingga dapat mengantarkan generasi bangsa yang memiliki karakteristik sebagai berikut:

Pertama, bertakwa yang ditandai dengan ciri-ciri orang beriman: mampu membangun hubungan dengan Allah, dengan manusia dan dengan alam sekitar, menegakkan syari' at-Nya, benar, amanah, ikhlas, rela berkurban, sabar dan mampu bersyukur.

Kedua, cendekia yang ditandai dengan selalu berfikir aktif, cerdas, haus akan ilmu, belajar sepanjang hayat, aktif meneliti dan melakukan pengembangan serta ahli dan profesional dalam bidang yang menjadi bakat dan minatnya. Ketiga, prima fisik yang ditandai dengan sehat jasmani, ahli dan terampil, kuat dan memiliki stamina yang tinggi (Dokumentasi visi SDIT Lukman alHakim).

Tujuan pendidikan SDIT Lukman alHakim dalam menyelenggarakan pendidikan yang integral dengan tiga karakteristik di atas mengindikasikan bahwa SDIT Lukman al-Hakim ingin mencetak kader-kader yang unggul dalam berbagai bidang keilmuan. Hal senada juga terungkap dalam wawancara dengan Bapak Nugroho selaku Kepala SDIT Lukman al-Hakim:

Terpadu dalam hal konten (isi) yaitu tidak mengenal mata pelajaran umum dan mata pelajaran agama. Semua mata pelajaran adalah agama karena setiap mata pelajaran yang di- pelajari anak adalah untuk mengantarkan anak yang bertauhid. Terpadu di sini mengandung tiga aspek yakni...tidak ada pemisahan antara mata pelajaran agama dan pelajaran umum. Kurikulumnya berbasis tauhid karena setiap mata pelajaran yang dipelajari anak adalah untuk mengantarkan anak supaya bertauhid" (Wawancara dengan Kepala SDIT Lukman al-Hakim, Nugroho).

Melihat tujuan pendidikan SDIT Lukman al-Hakim dan juga hasil wawancara dengan Bapak Nugroho dapat disimpulkan bahwa dilihat dari perspektif pandangannya mengenai ilmu pengetahun, SDIT Lukman al-Hakim lebih dekat kepada pandangan para intelektual Muslim abad pertengahan (alGhazali dan Ibnu Kholdun) dibanding dengan pandangan dua kelompok lainnya (ilmuwan Barat dan Muslim ekstrem).

Dalam konteks Kristen kontemporer, pendekatan "integrasi” dipopulerkan Barbour, yang menyebut salah satu dari empat tipologi hubungan sains dan agama dengan "integrasi". Teolog cum fisikawan kristen ini dianggap sebagai salah seorang peletak dasar wacana sains dan agama yang berkembang di Barat, tetapi pengaruhnya kini telah amat menyebar berkat penerjemahan buku-bukunya, termasuk di Indonesia. Barbour memetakan empat pandangan dalam tipologi yang dibuatnya, yakni konflik, independensi, dialog dan integrasi.

Ada beberapa pandangan mengenai integrasi ilmu pada stake holder di SDIT Lukman al-Hakim Surakarta. Ada yang berpandangan bahwa ilmu itu sikapnya netral, tidak mengenal apakah ilm Barat atau ilmu Islam. Hal ini terungkap dari wawancara dengan Bapak Nugroho selaku kepala SDIT Lukman al-Hakim:

“....ilmu itu kan sifatnya netral. Tidak peduli apakah ilmu itu dipelajari oleh orang Islam atau orang Barat.Pada zaman Nabi Muhammad Saw dan para shohabatnya banyak contoh yang menunjukkan bahwa ilmu itu sikapnya netral. Misalnya ketika Nabi memerintahkan Zaid bin Tsabit untuk mempelejari bahasa Yahudi demi kepentingan Islam. Pada zaman Umar juga banyak contohnya. Hal itu 
menunjukkan bahwa pandangan Islam terhadap ilmu itu bersifat netral." (Wawancara dengan Bapak Nugroho selaku Kepala SDIT Lukman al-Hakim).

Hal demikian juga dikuatkan hasil wawancara dengan Bapak Amin Suwarto, selaku Wakil Kepala Sekolah Bidang Kurikulum. Di kalangan intelektual Muslim sendiri, pandangan mengenai sifat ilmu, apakah ilmu itu bersifat objektif, bebas nilai, atau apakah ada perbedaan mendasar antara ilmu yang berkembang di dunia Barat dan Muslim masih terjadi perbedaan. Ada sebagian kalangan yang menafikan perbedaan tersebut, dan sebagian yang lain melihat secara nyata adanya perbedaan.

Bagi kelompok yang menafikan, yang merupakan mayoritas, ilmu pengetahuan bersifat objektif, sehingga perbedaan antara ilmu pengetahuan modern dan Islam adalah semu. Bagi kalangan ini, ilmu juga bersifat universal, sehingga bisa berlaku sama di mana saja, di Barat maupun di Timur. Sedangkan bagi kelompok kedua, yang membenarkan adanya perbedaan fundamental antara epistimologi modern dengan islami ilmu pengetahuan tidak bisa sama sekali terlepas dari subjektivitas sang ilmuwan, dan karena itu ilmu tidak bisa dikatakan objektif, bebas nilai, dan universal.

Salah seorang pendukung pendirian pertama (yang berpandangan ilmu itu objektif, bebas nilai, dan bersifat universal) adalah Parvez Hoodboy, seorang fisikawan muda yang cukup dikenal di Universitas Quadiazam, Pakistan. Dalam bukunya $I s$ lam and Science, Hoodboy menyatakan bahwa "tidak ada yang disebut ilmu yang islami, dan semua upaya untuk mengislamkan ilmu akan mengalami kegagalan." Alasannya tentu saja universalitas dan objektivitas ilmu. Untuk memperkuat argumennya, ia mengajukan kasus Abdus Salam dan Stevenweinberg, dua fisikawan yang berbagi hadiah nobel tahun 1976 dalam bidang fisika karena keduanya telah berhasil menyatukan kekuatan-kekuatan lemah elektroma- gnetik yang ada pada alam, padahal yang satu beragama Islam dan yang lain terus terang mengaku atheis.

Sebagaimana menurut skema Armahedi Mahzar dalam tataran konspesional bahwa tujuan lembaga pendidikan Islam harus dirumuskan kembali dalam konteks Islam, sepertinya sangat relevan dengan fenomena yang berkembang di SDIT Lukman al-Hakim. Tujuan SDIT Lukman al-Hakim adalah untuk mengantarkan peserta didik memiliki tauhid karenanya kurikulumnya berbasis tauhid.

Pertama, tujuan lembaga pendidikan adalah mendidik generasi yang senantiasa mengarahkan dirinya menjadi insan kamil yang memahami din al-Islam secara kaffah. Kedua, penilitian sebagai tujuan lembaga pendidikan harus dilihat dalam perspektif tauhid untuk mengenal sifat-sifat Yang Maha Pencipta secara lebih mendalam. Ketiga, pengabdian kepada masyarakat, sebagai tujuan perguruan tinggi, harus dilihat sebagai pengamalan ilmu untuk umat manusia seluruhnnya sebagai ekspresi dari tasykir: mensyukuri nikmat Allah. Secara ringkas, ta'allum dan tasyakur terintegrasi oleh tauhid.

Integrasi dalam tataran institusional, SDIT Lukman al-Hakim juga telah mengintegrasikan berbagai disiplin keilmuan dalam satu paket kurikulum. Mata pelajaran dari kementerian pendidikan dan kebudayaan, mata pelajaran dari kementerian Agama, dan mata pelajaran dari Pesantren di integrasikan secara utuh dan dikumpulkan menjadi satu wadah dengan konsep kurikulum berbasis tauhid.

Proses integrasi keilmuan di sekolah ini yang diwujudkan dalam pembelajaran adalah upaya untuk mempertemukan kembali antara ilmu-ilmu keagamaan dengan ilmu-ilmum umum sehingga tercapailah keterpaduan diantara dua keilmuan tersebut. Dari proses ini diharapkan akan menjadi solusi dari berbagai krisis yang diakibatkan oleh ketidakpedulian suatu ilmu terhadap ilmu yang lain yang selama ini terjadi baik 
dalam lembaga pendidikan Islam maupun lembaga pendidikan umum.

\section{Kurikulum Berbasis Tauhid}

Adanya integrasi ilmu antara ilmu agama dan ilmu umum menuntut adanya perubahan dan penyesuaian konsep kurikulum yang diimplementasikan di sekolah. Di SDIT Lukman al-Hakim, implikasi dari integrasi antara ilmu agama dan ilmu umum adalah dengan diberlakukannya kurikulum terpadu yang dinamakan dengan istilah kurikulum berbasis tauhid.

Adanya dikotomi ilmu pengetahuan yang menempatkan ilmu umum dan ilmu agama secara terpisah telah banyak menimbulkan terpecahnya jiwa anak didik. Di satu sisi anak belajar ilmu agama tetapi di sisi lain anak didik belajar ilmu umum yang terlepas dan tidak ada hubungannya dengan agama. Alasan inilah yang menjadi latar belakang berdirinya Sekolah Dasar Islam Terpadu (SDIT) Lukman al-Hakim Surakarta. Hal demikian terungkap dari wawancara dengan Kepala SDIT Lukman al-Hakim, Bapak Nugroho yang menuturkan bahwa:

\footnotetext{
"Kurikulum yang diterapkan di sekolahsekolah umum ataupun di sekolah-sekolah agama pada umumnya menyebabkan jiwa anak menjadi terpecah. Kurikulum yang berjalan saat ini adalah kurikulum yang mengadopsi kurikulum pendidikan Barat dan kurikulum pendidikan Barat adalah kurikulum yang bersifat sekularis dan materialis sehingga masih banyak melupakan aspek-aspek kejiwaan anak. Di satu sisi anak belajar ilmu agama tetapi di sisi lain anak belajar ilmu umum yang terlepas dan tidak ada hubungannya sama sekali dengan ilmu agama. Hal itu berakibat mengacaukan jiwa anak didik. Berawal dari situ SDIT Lukman al-Hakim berusaha untuk merumuskan kurikulum yang terpadu..."(Wawancara dengan Kepala SDIT Lukman al-Hakim, Bapak Nugroho).
}

Dari hasil wawancara dengan Bapak Nugroho diketahui bahwa kurikulum terpadu dengan istilah kurikulum berbasis tauhid yang diterapkan di SDIT Lukman al-Hakim dilatarbelakangi oleh adanya konsep dikotomi ilmu pengetahuan yaitu adanya pemisahan antara ilmu-ilmu agama dan ilmu-ilmu umum.

Hal senada diungkapkan oleh Bapak Yadi, S.Pd. yang menuturkan bahwa:

“...terpadu di sini adalah terjemahan dari kata integral. Konsep ini berawal dari konsep ilmu. Pada dasarnya semua ilmu itu berasal dari Allah swt baik itu ilmu bahasa, ilmu sosial, ilmu alam maupun ilmu-ilmu yang lain. Tetapi karena ilmu itu dilahirkan oleh bidan (ilmuwan) maka nuansa ilmu itu disesuaikan dengan ideologi bidan yang melahirkan. Bidan sekuler akan melahirkan ilmu yang sekuler sedangkan bidan yang bertauhid akan melahirkan ilmu yang berbasis tauhid..." (Wawancara dengan BapakYadi, Guru Mata Pelajaran Bahasa Indonesia).

Dari ungkapan tersebut dapat diketahui bahwa konsep kurikulum terpadu yang diterapkan di SDIT Lukman al-Hakim dilatar belakangi oleh adanya dikotomi ilmu yaitu antara ilmu-ilmu agama dan ilmu-ilmu umum.

Menurut penuturan Bapak Nugroho, maksud dari konsep kurikulum terpadu di SDIT Lukman al-Hakim meliputi tiga aspek yakni:

a. Terpadu dalam hal konten (isi) yaitu tidak mengenal mata pelajaran umum dan mata pelajaran agama. Semua mata pelajaran adalah agama karena setiap mata pelajaran yang dipelajari anak adalah untuk mengantarkan anak yang bertauhid. Dalam hal ini Bapak Nugroho mengatakan, "terpadu di sini mengandung tiga aspek yakni...tidak ada pemisahan antara mata pelajaran agama dan pelajaran $\mathrm{u}-$ mum. Kurikulumnya berbasis tauhid karena setiap mata pelajaran yang dipelajari anak adalah untuk mengantarkan anak supaya bertauhid".

b. Terpadu dalam hal subjek belajar yaitu berusaha untuk memadukan antara aspek 
kognitif, afektif, dan psikomotorik peserta didik.

c. Terpadu dalam penyelenggaraan yakni antara Kementerian Pendidikan dan Kebudayaan, Kementerian Agama, dan Pesantren (Wawancara dengan Kepala SDIT Lukman al-Hakim, Bapak Nugroho).

Usaha yang dilakukan untuk merumuskan keterpaduan dalam hal konten, secara teknis diwujudkan dengan menghilangkan sekat antara mata pelajaran agama dan mata pelajaran umum. Jadi selain dalam mata pelajaran Hadist, Tarikh, al-Qur'an, Akhlak, dan Fikih, materi agama juga disampaikan melalui semua mata pelajaran umum. Terpadu dalam aspek subjek belajar diwujudkan dengan menciptakan proses pembelajaran yang memadukan antara ketiga ranah yaitu ranah afektif, kognitif, dan psikomotorik secara bersamaan. Sedangkan keterpaduan dalam hal penyelenggaraan dilakukan dengan menerapkan kurikulum yang memuat mata pelajaran dari kurikulum Kementerian Pendidikan dan Kebudayaan dan mata pelajaran dari kurikulum pesantren.

Sedangkan Bapak Amin Suwarto menuturkan bahwa terpadu di sini juga memiliki arti terpadu pada lingkungan sekolah, rumah, dan masyarakat. Artinya adalah keterpaduan antara pendidikan di lingkungan sekolah, lingkungan keluarga, dan lingkungan masyarakat. Untuk maksud tersebut misi sekolah tidak hanya mendidik siswa akan tetapi juga mendidik orang tua siswa dan masyarakat sekitar.

Berdasarkan hasil wawancara dengan ketiga sumber di atas terungkap bahwa konsep kurikulum terpadu di SDIT Lukman alHakim mengandung maksud: pertama, Terpadu dalam ilmu agama dan ilmu umum, dalam pelaksanaannya tidak ada pemisahan antara ilmu agama dan ilmu umum karena pada dasarnya sumber dari segala ilmu itu satu yaitu Allah swt. Kedua, terpadu dalam aspek subjek belajar yang meliputi aspek kognitif, afektif, dan psikomotorik yang di- wujudkan dengan pelaksanaan pembelajaran yang menyeimbangkan ketiga ranah tersebut secara bersamaan. Ketiga, terpadu dalam penyelenggaraan antara Kementerian Pendidikan dan Kebudayaan dan pesantren. Dilakukan dengan memadukan antara mata pelajaran yang berasal dari kurikulum Kementerian Pendidikan dan Kebudayaan dan mata pelajaran yang berasal dari kurikulum pesantren. Keempat, terpadu dalam tiga lingkungan belajar yaitu lingkungan keluarga, sekolah, dan masyarakat. Dalam hal ini, misi sekolah tidak hanya mendidik siswa akan tetapi juga mendidik orang tua siswa dan masyarakat.

\section{Kesimpulan}

Integrasi ilmu merupakan sebuah keniscayaan untuk mencetak anak didik yang memiliki kepribadian integratif, bukan anak didik yang mengalami split personality. Di SDIT Lukman al-Hakim wujud integrasi diterapkan dalam pengembangan kurikulum yang terpadu antara ilmu umum dan agama. Keterpaduan kurikulum di SDIT Lukmanul Hakim mencakup tiga hal sebagai berikut: Pertama, terpadu dalam hal konten (isi) yaitu tidak mengenal mata pelajaran umum dan mata pelajaran agama. Semua mata pelajaran adalah agama karena setiap mata pelajaran yang dipelajari anak adalah untuk mengantarkan anak yang bertauhid. Terpadu di sini bermakna tidak ada pemisahan antara mata pelajaran agama dan pelajaran umum. Kedua, Terpadu dalam hal subjek belajar yaitu berusaha untuk memadukan antara aspek kognitif, afektif, dan psikomotorik peserta didik. Dan ketiga, terpadu dalam penyelenggaraan yakni antara Kementrian Pendidikan dan Kebudayaan, Kementrian Agama, dan Pesantren.

Implikasi dari paradigma ilmu yang integratif di SDIT Lukman al-Hakim adalah adalah terbentuknya kurikulum berbasis tauhid. Disebut kurikulum berbasis tauhid karena setiap mata pelajaran yang dipelajari a- 
nak adalah untuk mengantarkan anak supaya bertauhid. Pengembangan kurikulum berbasis tauhid diharapkan dapat mencetak para lulusan yang menguasai ilmu-ilmu modern yang disertai dengan pondasi karakter keagamaan yang kokoh sehingga anak didik lebih siap dalam menghadapi perkembangan zaman ke depan.

\section{DAFTAR PUSTAKA}

Ahmad, Amrullah. "Kerangka Dasar Masalah Paradigma Pendidikan Islam", dalam Muslih Usa, Pendidikan Islam di Indonesia. Yogyakarta: Aditia Media, 1987.

Al-Faruqy, Ismail Raji', Islamization of Knowledge: Principle and Prospective" dalam Islam: Source and Purpose of Knowledge, USA: Virginia, 1982.

Bastaman, Hanna Djumhana, Integrasi Psikologi dengan Islam, Yogyakarta: Pustaka Pelajar, 1997.

Damanik, Ali Said, Fenomena Partai Keadilan Sejahtera, Transformasi 20 tahun Gerakan Tarbiyah di Indonesia, Jakarta: Teraju, 2003.

Departemen Pendidikan dan Kebudayaan, Kamus Besar Bahasa Indonesia, Jakarta: Balai Pustaka, 1989.

Echols, Jhon M. dan Hasan Sadily. Kamus Inggris-Indonesia. Jakarta: PT Gramedia Pustaka Utama, 1992.

George R. Ritzer dan Douglas J Goodman, Teori Sosiologi Modern, Diterj.oleh: Tri Wibowo Budi Santoso, Cet.IV, Jakarta: Kencana Prenada Media Group, 2007.

Hefner, Robert W. 1993. "Islam, State, and Civil Society: ICMI and the Struggle for the Indonesia Middle Class." Indonesia. Number 56(October).

Hisyam, Usamah, Sepanjang Jalan Dakwah Tifatul Sembiring, Jakarta: PT Dharmapena Citra Media, 2012.
Kartanegara, Mulyadhi, Integrasi Ilmu, Jakarta: Mizan, 2005.

Kountur, Roni, Metode Penelitian untuk Penulisan Tesis, Jakarta: PPM, 2005.

Kuntowijoyo. 1985. "Muslim Kelas Menengah Indonesia 1910-1950: Sebuah Pencarian Identitas."Prisma No. 11.

Moeflich Hasbullah, (http://www.academia.edu/3589226/Teori Habitus dan Kelas Menengah Muslim Indonesia).

Moleong, Lexy J., Metodologi Penelitian Kualiatif, Bandung: PT Remaja Rosda Karya, 2005.

Narko, Cholid, dan Abu Achmadi, Metodologi Penelitian, Jakarta: PT Bumi Aksara, 2005.

Pratiknya, Ahmad Watik, 'Identifikasi Masalah Pendidikan Agama Islam di Indonesia', dalam Muslih Usa (ed.), Pendidikan di Indonesia antara Cita dan Fakta, Yogyakarta: PT Tiara Wacana, 1991.

Sadily, Hasan, dan Jhon M. Echols, Kamus Inggris-Indonesia, Jakarta: PT Gramedia Pustaka Utama, 1992.

Sardar, Ziauddin, Jihad Intelektual: Merumuskan Parameter-parameter Sains Islam, Ae Priyono (Ed), Surabaya: Risalah Gusti, 1998.

Sardar, Ziauddin, Rekayasa Masa Depan Peradaban Muslim, Terj. Rahmanai Astuti, Bandung: Mizan, 1998.

Sukmadinata, Nana Syaudih, Metodologi Penelitian Pendidikan, Bandung: PT. Remaja Rosda Karya, 2004.

Syafii Anwar, Pemikiran dan Aksi Islam Indonesia Sebuah Kajian Politik tentang Cendikiawan Muslim Orde Baru, Jakarta: Penerbit Paramadina, 1995.

Usa, Muslih, Pendidikan di Indonesia antara Cita dan Fakta, Yogyakarta: PT Tiara Wacana, 1991.

Wawancara dengan Amin Suwarto, wakil kepala bidang kurikulum, SDIT Lukman al-Hakim Surakarta 
Wawancara dengan Nugroho, kepala SDIT Lukman al-Hakim Surakarta.

Wawancara dengan Yadi, Guru Bahasa Indonesia SDIT Lukman al-Hakim Surakarta. 